\title{
A profundidade da vida: interfaces e aproximações da teologia com as ciências da vida em relação ao paradigma ecológico de Leonardo Boff
}

\author{
Orientador: Jenura Clotilde Boff \\ Doutorando: Gean Carlos dos Santos \\ Área de Concentração: Teologia Sistemático-Pastoral \\ Linha de Pesquisa: Religião e Modernidade
}

A nossa pesquisa surgiu da constatação da emergência de um novo paradigma civilizacional, capaz de resgatar as dimensões da vida humana e do cosmos, especialmente dos seres vivos mais fragilizados e ameaçados e de toda a comunidade da vida. Como teólogos e teólogas devemos ter atenção e perspicácia ao elaborar uma teologia, capaz de superar o antropo e o androcentrismo, compreendendo a pessoa humana como inter e retro relacionada, responsável pelas gerações que estão por vir e por toda a criação. A nossa pesquisa quer contribuir pró-ativamente, para que a opção pelos pobres e excluídos, a promoção da justiça, a proteção da vida e a ecologia como casa comum da humanidade sejam um referencial fundamental do interesse social da Igreja e da ação humana no mundo. Procuramos assimilar a compreensão contemporânea da vida, mediante as ciências da vida e a nova cosmologia, buscando suas interfaces e aproximações. Daí a relevância de Leonardo Boff, com a sua visão de Ecologia como casa comum de todos os seres vivos, fundamentada numa Ética que leva em consideração o grito dos pobres, o respeito pela vida a partir do cuidado, como direito e dever de todos, em vista de uma nova humanidade. Fazemos uma leitura teológica a partir das fontes da fé, Escritura e Tradição eclesial e um cotejamento entre as ciências, buscando pontos de contato com suas múltiplas interfaces e aproximações que servem como referenciais para nossa reflexão acerca do sentido teológico de vida a partir da ecologia Boffiana e sua relevância para o discurso teológico contemporâneo.

Palavras-chave: Teologia, Ciências, Vida, Respeito, Pobre, Ecologia, Sustentabilidade. 